\title{
Energy and Exergy Analysis of a Plane Reflector Integrated Photovoltaic-Thermal Water Heating System
}

\author{
Prem Sagar Naik and Arun Palatel \\ Department of Mechanical Engineering, National Institute of Technology Calicut, NIT Campus (PO), Calicut 673601, India \\ Correspondence should be addressed to Arun Palatel; arun.p@nitc.ac.in
}

Received 12 February 2014; Accepted 20 March 2014; Published 14 April 2014

Academic Editors: A. Al-Salaymeh, O. Ozgener, and H. Tanaka

Copyright ( 2014 P. S. Naik and A. Palatel. This is an open access article distributed under the Creative Commons Attribution License, which permits unrestricted use, distribution, and reproduction in any medium, provided the original work is properly cited.

\begin{abstract}
A photovoltaic-thermal water heating system is a hybrid energy conversion device transforming the incident solar radiation to yield electrical energy and thermal energy. Plane reflectors are found to be a convenient option for enhancing the solar radiation incident on the collector plane. The present work investigates the performance of a photovoltaic-thermal water heater integrated with a plane reflector mounted on the top edge of the collector for the tropical climate of Calicut $\left(11.25^{\circ} \mathrm{N}, 75.78^{\circ} \mathrm{E}\right)$. Performance testing of the system has been carried out for the winter season of the location. The variations in thermal and electrical output are studied for various inclination angles of the reflector. The system performance is evaluated on the basis of system energy efficiency and exergetic efficiency. It is observed that there is a significant enhancement in the thermal and electrical output of the system with the integration of the reflector as compared to the system without the reflector. For the present system, the reflector tilt angle in the range of $85-100^{\circ}$ has been found to be suitable in terms of enhanced system output and exergetic efficiency for the winter conditions of Calicut.
\end{abstract}

\section{Introduction}

Simultaneous utilisation of electrical energy and thermal energy using hybrid photovoltaic-thermal (PV/T) systems is a key area of interest in the context of renewable energy utilisation. Considering the fact that demand of heat and electricity is concurrent in many applications, it is logical to integrate both systems to obtain higher energy output with improved efficiency. An ordinary photovoltaic (PV) module converts only about $4-17 \%$ of the incident solar energy into electricity, depending on the type of cells used and the ambient conditions. Many times, the cell working temperature may be as high as $50^{\circ} \mathrm{C}$ above the ambient temperature. This may result in a reduction in the efficiency of the cell (about $0.4 \%$ per unit temperature rise for crystalline silicon cells) and could adversely affect the module structure [1]. By transferring the thermal energy from the module to a fluid stream of air or water, the electricity yield can be enhanced from the photovoltaic system by improving its efficiency of operation. In the case of water as the coolant in a $\mathrm{PV} / \mathrm{T}$ system, hot water can be used for domestic applications for low capacity systems, and in the case of larger capacity systems the integrated system may find application in process industries where low and medium temperature level thermal energy is desired. For systems with air as working fluid, hot air can be utilised for applications like space heating and for agricultural needs like drying of crops and seeds. The electrical yield from the PV/T system can either be used directly or be supplied to the grid. Improved energy performance, lesser overall space requirement, and lower costs are the notable advantages of PV/T systems in general. Water heating systems using solar flat plate collectors have been recognized as a cost effective option, especially for domestic applications. It is considered as a matured technology which is reasonably commercialized worldwide [2]. Extensive experimental and theoretical studies are reported for their performance assessment. Recently, experimental and model based studies on thermosyphon domestic solar water heaters using flat plate collectors highlighting the importance of selective coating with respect to freezing temperature of water had been presented by Tang et al. [3]. Investigation of the thermal performance of a solar water heating system with 
flat plate collectors in a moderate climate with respect to daily, monthly, and annual performance has been reported by Ayompe and Duffy [4].

The liquid PV/T collectors are similar in construction to ordinary liquid flat-plate collectors. It essentially includes an absorber plate with water tubes, onto which PV would be laminated or glued. Considerable amount of work had been reported illustrating the performance analysis of $\mathrm{PV} / \mathrm{T}$ systems at various locations under varying operating conditions. Dynamic simulation models for serpentine PV/T system considering one-dimensional, two-dimensional, and three-dimensional models validated by experimentation had been illustrated [5]. Simulation study of PV/T water system (operating under passive and active modes) using TRNSYS software had been presented [6]. The design and testing of a PV/T water heater system of 200 litres capacity under outdoor conditions for the climate of New Delhi had been illustrated [7]. Mathematical formulations for assessing the performance of the collector were also detailed. The influence of parameters like mass flow rate of the working fluid, irradiation, wind velocity, and so forth on the first and second law efficiencies of a hybrid PV/T water heater system had been detailed by Chow et al. [8]. Variations of energy efficiency and total exergy efficiency of the overall system had been described for various operating conditions. An expression based on system energy balance for the outlet water temperature of a hybrid photovoltaic-thermal solar water heater had been presented by Tiwari et al. [9]. A single glazed flat plate PV/T solar collector was designed and methods of improving the system using a two-dimensional computational model had been described [10]. Overall energy efficiency and exergy efficiency of microchannel solar cell based PV/T system for different climatic regions of India had been reported by Agrawal and Tiwari [11]. Recently, dynamic performance modelling of a photovoltaic-thermal collector for water heating in buildings using simulation model based approach was presented which investigated the effect of the series connection of modules, inlet water temperature, and mass flow rate of water [12]. A test rig based study to measure and assess the performance of photovoltaic-thermal system as compared to a conventional solar thermal has been illustrated by $\mathrm{He}$ et al. [13]. Energy balance based model of hybrid PV/T system incorporating phase change material had been illustrated. It was reported that, by incorporating phase change material in an optimised system, the electrical power output could be increased by about $9 \%$ with an average water temperature rise of $20^{\circ} \mathrm{C}$ [14]. It is well known that temperatures far greater than conventional flat plate collectors can be attained by the use of flat reflectors in such systems. The reflectors can significantly increase the amount of direct radiation reaching the collector. There have been several studies reported in the literature discussing the use of planar reflectors for enhancing the solar radiation incident on flat plate collectors. An analytical model for obtaining the solar irradiation on flat plate collectors augmented with planar reflectors had been developed by Bollentin and Wilk [15]. An overview of commercially available reflectors had been provided by Nostell et al. [16]. It was reported that silver, aluminium, and stainless steel are good reflector materials.
Theoretical analysis of the instantaneous, daily, and yearly augmentation in solar energy collection of a tilted flatplate solar collector improved by a plane reflector had been reported by Hussein et al. [17]. The influence of aluminium based flat reflectors on the performance of a PV/T collector had been presented by Kostić et al. [18]. Theoretical study of a solar thermal collector with a flat plate top reflector which can be tilted forward or backward from vertical according to the seasons had been analysed by Tanaka [19]. Flat reflectors provide a simple and convenient option to enhance the irradiance on the plane of flat plate collector. It has been concluded based on previous studies on flat plate collectors that placement of the reflector either above or below the collector affects the system performance. It is preferable to have two reflectors placed, one above and the other below the collector which may be suitably adjusted for different seasons to enhance the incident energy available to the collector.

The present work investigates the energy and exergy performance of a PV/T water heater integrated with a single plane reflector mounted on the top edge of the collector. This is considering the simplicity of design and in view of the space limitations. Also, based on previous studies it has been concluded that for a collector kept at an inclination equal to the latitude of the location, placement of the reflector above the collector has been recommended for winter conditions [20]. However, to assess the yearly performance of such systems, placement of reflectors above and below the collector needs to be considered. In the present work, based on detailed energy and exergy analysis of the system, the range of reflector tilt angle suitable for the winter conditions of Calicut has been proposed.

\section{Reflector Integrated Photovoltaic-Thermal Water Heating System}

A natural circulation $\mathrm{PV} / \mathrm{T}$ water heating system with the photovoltaic module attached integrally on top of the absorber plate is analysed in this study. Performance analysis of the system has been carried out based on the testing of the system in the Solar Energy Laboratory of the National Institute of Technology Calicut $\left(11.25^{\circ} \mathrm{N}, 75.78^{\circ} \mathrm{E}\right)$, during the winter months (November to January) corresponding to this location. The climate of Calicut (located in southern India) is moderate, with an average temperature of $27^{\circ} \mathrm{C}$ during the months of November to January. The major specifications of the experimental system are provided in Table 1. The absorber plate with the integrated module and glass cover assembly are maintained in an insulated box to minimize the thermal energy losses. The glass is securely fixed in the collector with rubber sealing. The PV module is fixed at the upper portion of the absorber plate. Monocrystalline silicon solar cells having a nominal efficiency of $14 \%$ at standard test conditions are used in the module. The module has a rated power of $75 W_{p}$. The whole absorber-tube is made of copper having sheet-intube design. The absorber plate has an area of $1.5 \mathrm{~m}^{2}$. Thermal energy is transferred from the module to the absorber plate providing useful energy gain to the water flowing through the tubes. The ends of the copper tubes are connected to two 
TABLE 1: Specification of the PV/T water heating system.

\begin{tabular}{lc}
\hline Component details & Specifications \\
\hline Capacity of storage tank & 100 liters \\
Area of collector & $2 \mathrm{~m} \times 1 \mathrm{~m}$ \\
Tube diameter & $12.2 \mathrm{~mm}$ \\
Tube material & Copper \\
Absorber plate thickness & $0.12 \mathrm{~mm}$ \\
Plate material & Copper \\
Air gap thickness between glass cover and & $25 \mathrm{~mm}$ \\
absorber plate & Glass wool \\
Insulation & $25 \mathrm{~mm}$ \\
Thickness of insulation & $100 \mathrm{~mm}$ \\
Thickness of aluminum casing of the & \\
collector & $20^{\circ}$ \\
Inclination of collector with the & $0.425 \mathrm{~cm}$ \\
horizontal & Single crystalline \\
Thickness of glass & silicon \\
PV module material & 0.7 \\
Fill factor & $0.6 \mathrm{~m}{ }^{2}$ \\
Area of PV module & $4.5 \mathrm{~mm}$ \\
Thickness of PV module & $2 \mathrm{~m} \times 1 \mathrm{~m}$ \\
Reflector area & Aluminum \\
Reflector material & $0.2 \mathrm{~mm}$ \\
Thickness of reflector & \\
\hline
\end{tabular}

traverse headers. In the present study, the effect of a plane reflector on the performance of the PV/T water heater has been experimentally investigated. The plane reflector made of aluminium has been incorporated to the system which is fixed to the top edge of the collector. The reflecting surface is fixed to a movable frame arrangement. The movable frame arrangement permits varying levels of tilt for the reflector surface. Schematic diagram of the PV/T system with the reflector is given in Figure 1. The movable frame arrangement enables the tilting of the reflector with respect to the PV/T collector plane from $\psi=0^{\circ}$ corresponding to the reflector plane parallel to the $\mathrm{PV} / \mathrm{T}$ collector to $\psi=180^{\circ}$ with the reflector plane and $\mathrm{PV} / \mathrm{T}$ collector plane coinciding. $\mathrm{PV} / \mathrm{T}$ collector is positioned at an angle of $\beta=20^{\circ}$ with respect to the horizontal plane and is south-oriented. The photographic view of the experimental setup is given in Figure 2. As the plane reflector provided in the system additionally enhances the solar irradiance level incident on the collector plane, there is expected increase in the thermal and electrical output from the system as compared to the base case without the reflector. It is of interest to investigate the effect of incorporating the reflector on the overall performance of the system. The following parameters are measured during the experimentations in order to analyze the performance of $\mathrm{PV} / \mathrm{T}$ collector with and without plane reflector: (i) ambient temperature, (ii) inlet temperature of water, (iii) outlet temperature of water, (iv) temperature of PV module, (v) temperature of absorber plate, (vi) global and diffuse irradiance on the collector surface, and (vii)

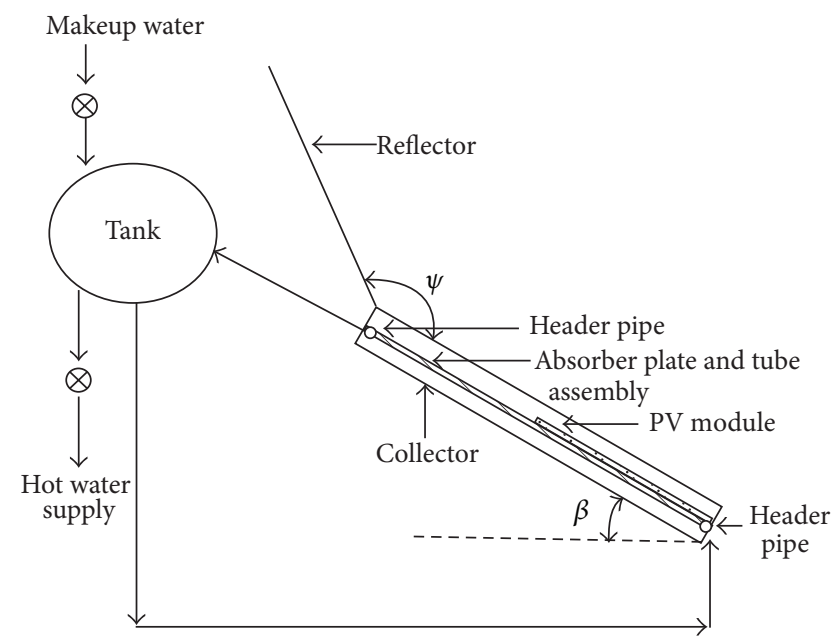

FIGURE 1: Schematic of the experimental setup.

TABLE 2: Range and accuracy of major instruments.

\begin{tabular}{lcc}
\hline Instrument & Range & Accuracy \\
\hline Pyranometer & 0 to $1800 \mathrm{~W} / \mathrm{m}^{2}$ & $\pm 5 \%$ of full scale \\
External temperature & $-40^{\circ}$ to $65^{\circ} \mathrm{C}$ & $\pm 0.5^{\circ} \mathrm{C}$ under $43^{\circ} \mathrm{C}$, \\
sensor & & $\pm 1^{\circ} \mathrm{C}$ over $43^{\circ} \mathrm{C}$ \\
Thermocouple & -200 to $1250^{\circ} \mathrm{C}$ & $0.75 \%$ above $0^{\circ} \mathrm{C}$, \\
(K type) & & $2.0 \%$ below $0^{\circ} \mathrm{C}$ \\
\hline
\end{tabular}

module output. The irradiance incident on the PV/T collector surface has been recorded by means of Emcon pyranometer. Measurements have been performed over ten-minute intervals. The temperature measurements were done by calibrated $\mathrm{K}$-type thermocouples with a sensitivity and temperature range of approximately $41 \mu \mathrm{V} /{ }^{\circ} \mathrm{C}$ and $-200^{\circ} \mathrm{C}$ to $+1350^{\circ} \mathrm{C}$, respectively. An automatic weather station (DAVIS Vantage PRO) has been used for the measurement of important meteorological parameters, such as ambient temperature and wind speed. All such weather related data have been recorded in thirty-minute intervals. Performance test of the system has been conducted over representative days of the winter months under clear sky conditions. The flow is regulated and a constant mass flow rate of water of $0.017 \mathrm{~kg} / \mathrm{s}$ is maintained through the collector. The solar irradiance is measured with help of the pyranometer over ten-minute intervals to obtain the average value over the hour of the day. Temperature measurements for various parts of the system are done over hourly interval with help of K-type thermocouples. The PV module output is recorded every hour with help of Metravi digital multimeter. The measurements are carried out for the entire day during the periods of sunshine. Experiments have been conducted with varying tilts of the plane reflector for different day of the months concerned. The range and accuracy of the major instruments are given in Table 2.

\section{Evaluation of System Performance}

The detailed energy analysis of the basic system without the reflector has been already reported [21]. The energy 


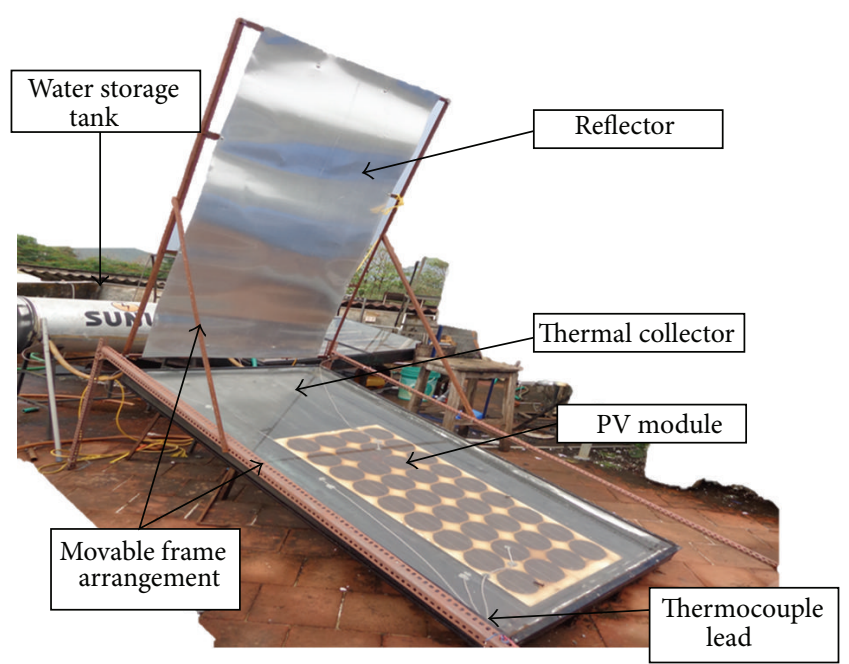

FIGURE 2: Photographic view of the photovoltaic-thermal water heating system.

performance assessment of the reflector integrated $\mathrm{PV} / \mathrm{T}$ water heating system on the basis of first and second law efficiencies is detailed in this section. The overall system performance can be evaluated by the instantaneous energy efficiency of the system $\left(\eta_{\mathrm{PVT}}\right)$ calculated by the following relation:

$$
\eta_{\mathrm{PVT}}=\frac{\dot{Q}_{u}+P_{e}}{I_{T} A_{c}}
$$

where $\dot{Q}_{u}$ is the rate of useful heat gain by water, $P_{e}$ is electrical power output from the module, and $I_{T}$ is the global solar irradiance on the collector area $\left(A_{c}\right)$. The overall energy efficiency of PV/T system is expressed in terms of the thermal efficiency of the collector $\left(\eta_{t}\right)$, the module efficiency $\left(\eta_{\mathrm{PV}}\right)$, and the PV cell packing factor $(\xi)$ as

$$
\eta_{\mathrm{PVT}}=\eta_{t}+\xi \eta_{\mathrm{PV}}
$$

The packing factor is defined as

$$
\xi=\frac{A_{\mathrm{PV}}}{A_{c}} .
$$

In the above equation, $A_{\mathrm{PV}}$ represents the area of the module. The thermal efficiency of the collector $\left(\eta_{t}\right)$ is evaluated by

$$
\eta_{t}=\frac{\dot{Q}_{u}}{A_{c} I_{t}}=\frac{\dot{m} c_{p}\left(T_{f o}-T_{f i}\right)}{A_{c} I_{t}}
$$

where $\dot{m}$ is the mass flow rate of water (having specific heat $c_{p}$ ) and $T_{f o}$ and $T_{f i}$ are the temperatures of water at the collector outlet and inlet, respectively. The module efficiency is calculated by

$$
\eta_{e}=\frac{P_{e}}{A_{\mathrm{PV}} I_{T}}=\frac{V I}{A_{\mathrm{PV}} I_{T}} .
$$

Here $V$ and $I$ are the module voltage and current, respectively.
The exergy of a thermodynamic system is the maximum useful work that may be obtained from the system as it undergoes a reversible process that brings the system into total thermodynamic equilibrium with its environment. The exergetic efficiency of the system can be conveniently evaluated based on exergy input to the system and exergy output from the system. The exergy input (from the available solar radiation) to the system is estimated by the relation [22]

$$
\dot{X}_{\text {in }}=\left(1-\frac{T_{0}}{T_{s}}\right) A_{c} I_{T},
$$

where $T_{0}$ is the ambient temperature and $T_{s}$ the solar temperature taken as $6000 \mathrm{~K} \mathrm{[8].}$

The rate of exergy output from the module is essentially the power output from the module. Hence,

$$
\dot{X}_{\mathrm{PV}}=P_{e} .
$$

The rate of exergy output from the collector is calculated by the following relation:

$$
\dot{X}_{t}=\dot{Q}_{u}\left(1-\frac{T_{0}}{T_{f o}}\right) .
$$

The exergy efficiency of the system is defined as the ratio of the exergy output to the exergy input for the system. For the $\mathrm{PV} / \mathrm{T}$ system it may be expressed as [8]

$$
\varepsilon_{\mathrm{PVT}}=\varepsilon_{t}+\xi_{\mathrm{PV}} .
$$

In the above relation, the exergetic efficiency of the collector $\left(\varepsilon_{t}\right)$ is given by

$$
\varepsilon_{t}=\frac{\dot{X}_{t}}{\dot{X}_{\text {in }}} .
$$

The exergetic efficiency of the module $\left(\varepsilon_{\mathrm{PV}}\right)$ is given by

$$
\varepsilon_{\mathrm{PV}}=\frac{\dot{X}_{\mathrm{PV}}}{\dot{X}_{\mathrm{in}}} .
$$

The effect of the reflector is quantified by means of the enhancement factor. The enhancement factor $(E)$ has been already defined for a reflector integrated flat plate collector [20]. For a PV/T system, it may be defined as the ratio of energy collected on the collector surface over a specified time period for a reflector integrated PV/T system to that of a collector alone system with its tilt angle optimized over the same time period. Performance studies have been carried to investigate the influence of the reflector on the overall system. The variations of instantaneous energy efficiency and exergy efficiency over the day have been monitored at various inclinations of the reflector and also for the base case without the reflector.

\section{Results and Discussion}

The results of the performance testing of the PV/T water heating system integrated with a flat plate reflector system 


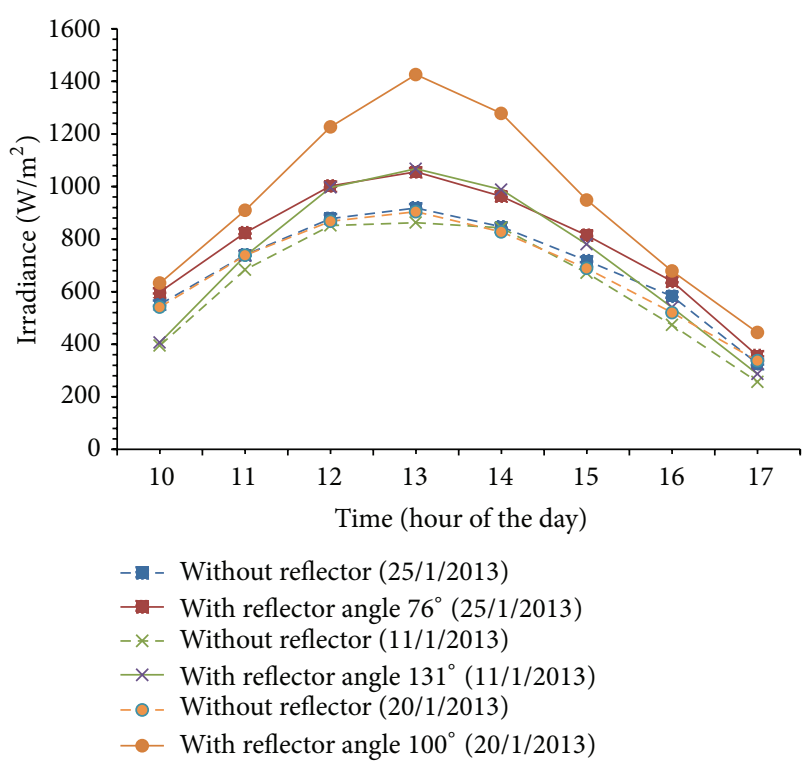

FIGURE 3: Comparison of the variation of solar irradiance over the collector for typical reflector tilt values.

corresponding to the winter months of Calicut are described in this section. It may be noted that experimentations had been carried out for various levels of tilt of the reflector $(\psi)$ ranging from $76^{\circ}$ to $131^{\circ}$. The lower limit of the reflector tilt was obtained considering the possibility of shadowing of the collector due to the reflector. The upper limit of the tilt angle was fixed such that beyond this value there was no significant increase in the irradiance level in the collector plane with the reflector incorporated. The variations in relevant performance parameters are illustrated for representative reflector tilts within this interval. The comparison of the system with and without the reflectors has been studied. As there was no setup available which could be used as a "control," comparisons had been done by studying the system performance separately with and without reflector considering those days when the variation of solar irradiance over the day was reasonably similar.

4.1. Variations of the System Parameters with Reflector Tilt. The hourly variations of solar irradiance on the collector plane, with and without the reflector, are illustrated for three reflector tilt angles, namely $76^{\circ}, 100^{\circ}$, and $131^{\circ}$, in Figure 3. The solar irradiance on the collector surface (with reflector incorporated) is measured as the mean value of irradiance measured at multiple points on the collector plane. The hourly values of enhancement factor obtained for these tilts of the reflector over a typical winter day are given in Figure 4 . The maximum value of the enhancement factor obtained over the day for different values of reflector tilt is illustrated in Figure 5. At the reflector tilt angle of $100^{\circ}$, total solar irradiance was found to be maximum for the location under study for the winter climate of Calicut. Hence, maximum values of temperatures for absorber plate and module also correspond to this reflector tilt. The variations of the average module temperature for representative reflector

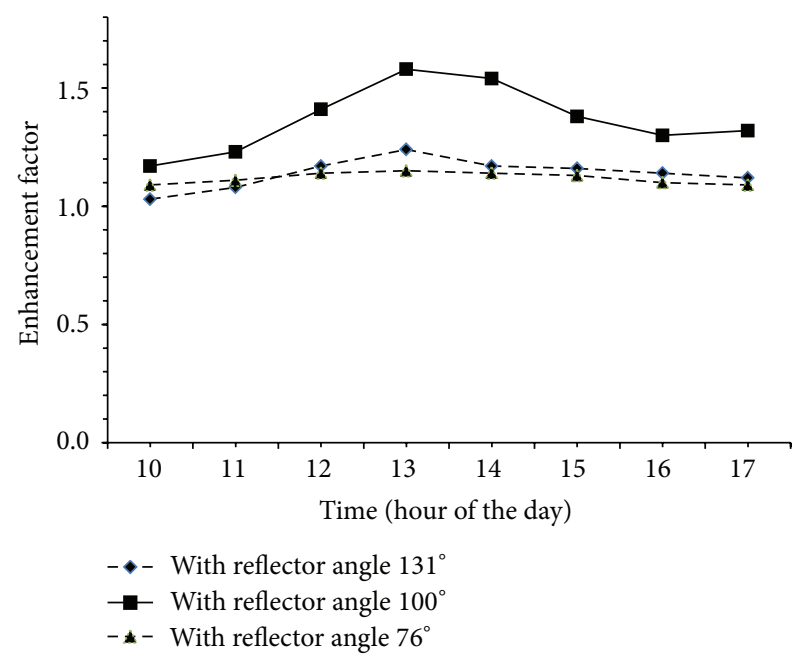

FIGURE 4: Comparison of variation in enhancement factors over the day for representative reflector inclinations.

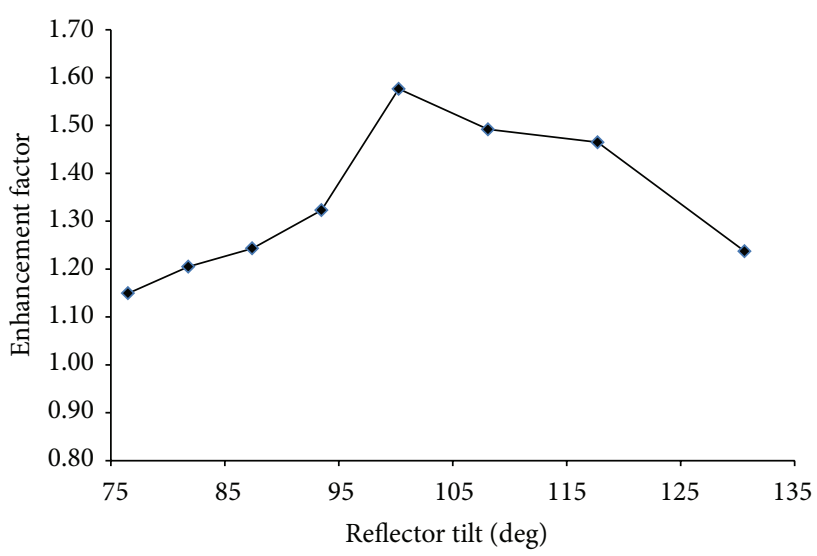

FIGURE 5: Variation of maximum enhancement factors for different reflector inclinations.

tilts are given in Figure 6 . The hourly module temperature variation without the reflector is also shown for comparison. The hourly variation of the average absorber temperature is also represented in Figure 6. The module temperature and absorber plate temperature show significant deviation with the reflector incorporated as compared to the base case without the reflector. At tilt angle where maximum irradiance is received, there is a need for further enhancing the heat transfer from the module to the water being circulated through the collector tubes. It is found that at reflector angle of $100^{\circ}$, maximum deviation between the module temperature and absorber plate temperature is observed. The variation in hourly electrical power from the system during the day for three different reflector inclinations is shown in Figure 7. As electrical energy generated by the module is directly proportional to total radiation incident on the collector, the electrical energy yield was found to be maximum at $100^{\circ}$ reflector inclination. Compared to the maximum module output without the reflector, $54 \%$ increase in the maximum 


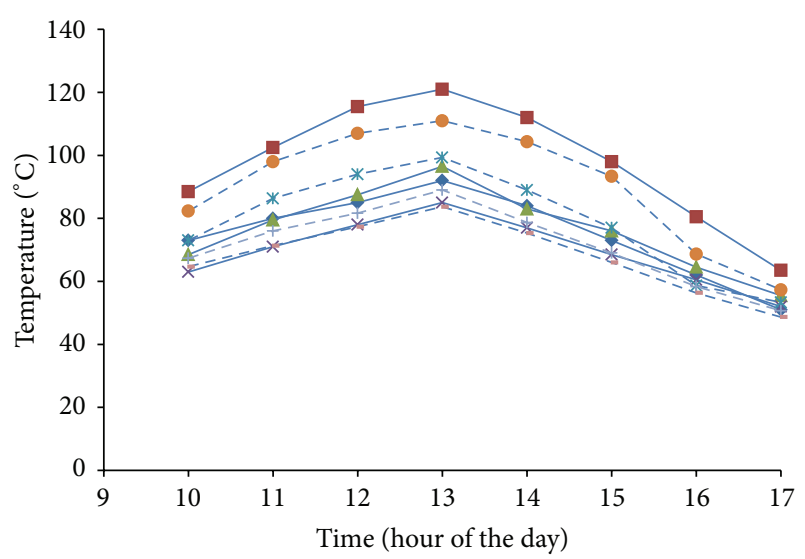

$\begin{array}{ll}\text { Module temperature } & \text { Plate temperature } \\ - \text { With reflector angle } 131^{\circ} & -*-\text { With reflector angle } 131^{\circ} \\ - \text { With reflector angle } 100^{\circ} & -- \text { - With reflector angle } 100^{\circ} \\ - \text { With reflector angle } 76^{\circ} & -+- \text { With reflector angle } 76^{\circ} \\ - \text { Without reflector } & --- \text { Without reflector }\end{array}$

FIGURE 6: Variation in average temperature of the module for different levels of reflector inclination compared with the system without the reflector.

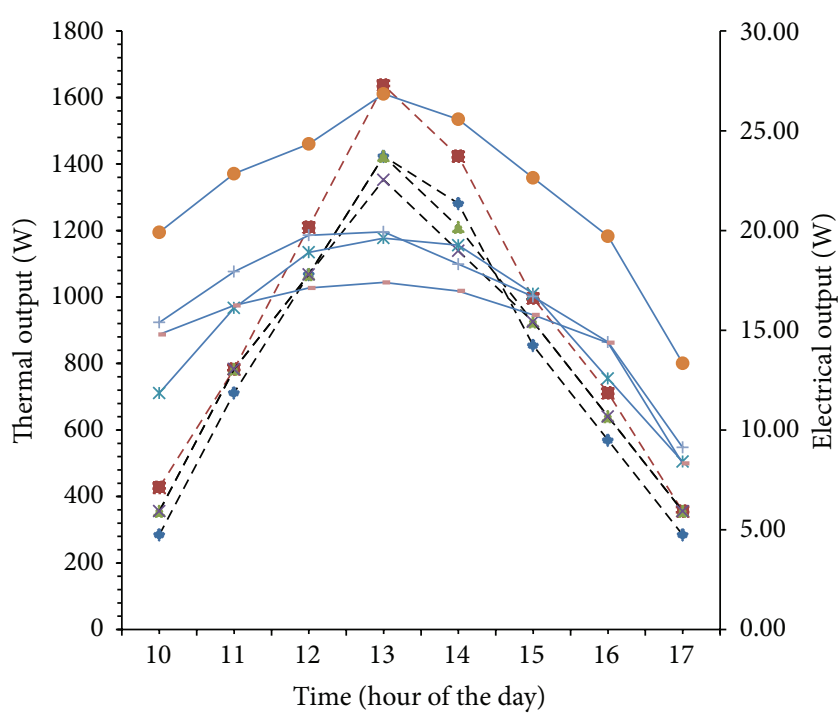
Thermal output
- - With reflector angle $131^{\circ}$
- With reflector angle $100^{\circ}$
- - With reflector angle $76^{\circ}$
$-\star$ - Without reflector
Electrical output
* With reflector angle $131^{\circ}$
- - With reflector angle $100^{\circ}$
-1 With reflector angle $76^{\circ}$
- Without reflector

FIGURE 7: Variation in the module power output and thermal output over the day for representative reflector inclinations compared with the system without the reflector.

power output over the day has been observed at this reflector tilt. The hourly variation of the rate of thermal energy from the collector over the day follows a similar trend as in the case of module power (Figure 7). With the reflector at tilt of $100^{\circ}$, the maximum rate of thermal energy from the collector has been enhanced by $21 \%$ compared to the situation without the reflector.

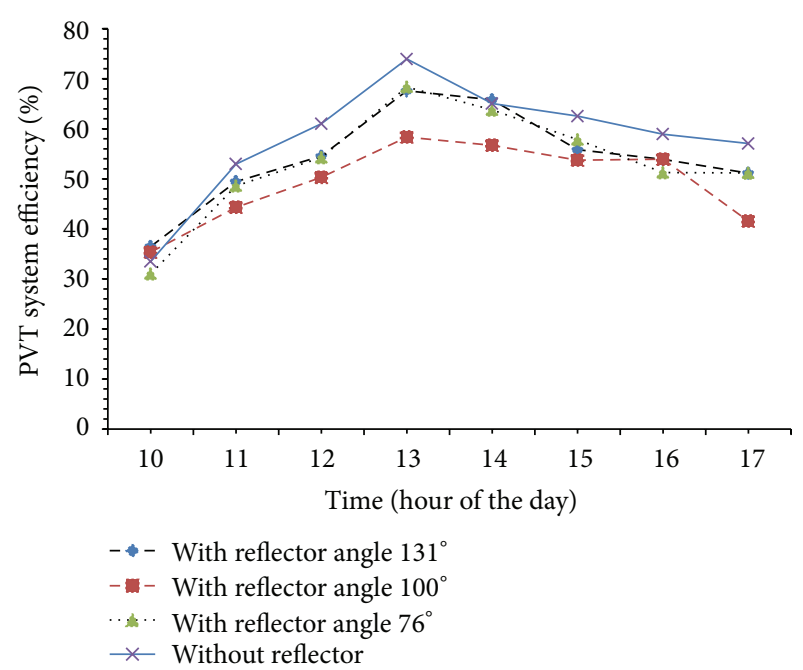

FIGURE 8: Variation of the system efficiency over the day for representative reflector inclinations compared with the system without the reflector.

4.2. System Performance. As expected, there is a marginal decrease in the energy efficiency of the module with increase in the module temperature. The variation in the instantaneous total energy efficiency of the PV/T system for different reflector tilts is illustrated in Figure 8. It has been observed that the maximum instantaneous efficiency of the reflector integrated collector (at a tilt of $100^{\circ}$ ) drops by $22 \%$ compared to the system without the reflector. However, on an average the drop in efficiency considering the entire day for the reflector integrated system is $15 \%$ as compared to the system without the reflector. It is observed that higher levels of irradiance on the collector plane increase the module temperature and the average temperature of the absorber plate thus decreasing the overall energy efficiency of the system. The integration of the reflector is recommended when there is a requirement of high thermal and electrical output from the system. The performance analysis of the system from the perspective of exergy has also been carried out. The hourly variation of the exergy input to the collector over the day is illustrated in Figure 9 for representative values of reflector tilts. It is observed that the maximum exergy input corresponds to the inclination providing higher levels of irradiance on the collector plane. The work potential or exergy of the electrical power from the module corresponds to the total electrical power available from it regardless of the temperature and pressure of the environment. Thermal exergy output has been found to be maximum at reflector tilt of $100^{\circ}$ corresponding to the condition of maximum irradiance on the collector plane (Figure 10). Both module exergy efficiency and collector exergy efficiency have been found to increase with the irradiance level on the collector. The variation of the instantaneous total exergy efficiency over the day for different reflector tilts is given in Figure 11. It has been observed that reflectors are a suitable option for low level concentration of solar irradiance. Though energy efficiency of the system drops due to higher operational temperature of 


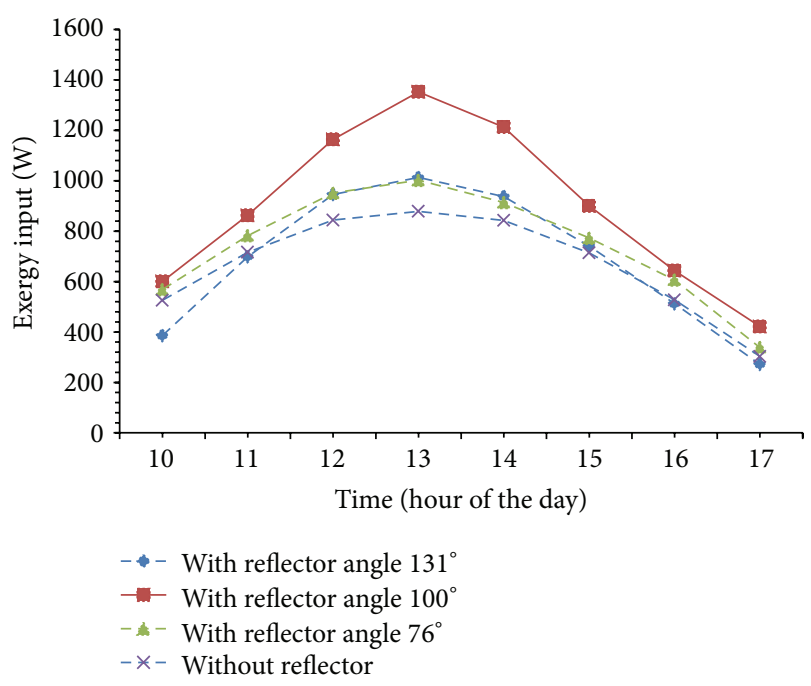

FIGURE 9: Variation of the exergy input over the day for representative reflector inclinations compared with the system without the reflector.

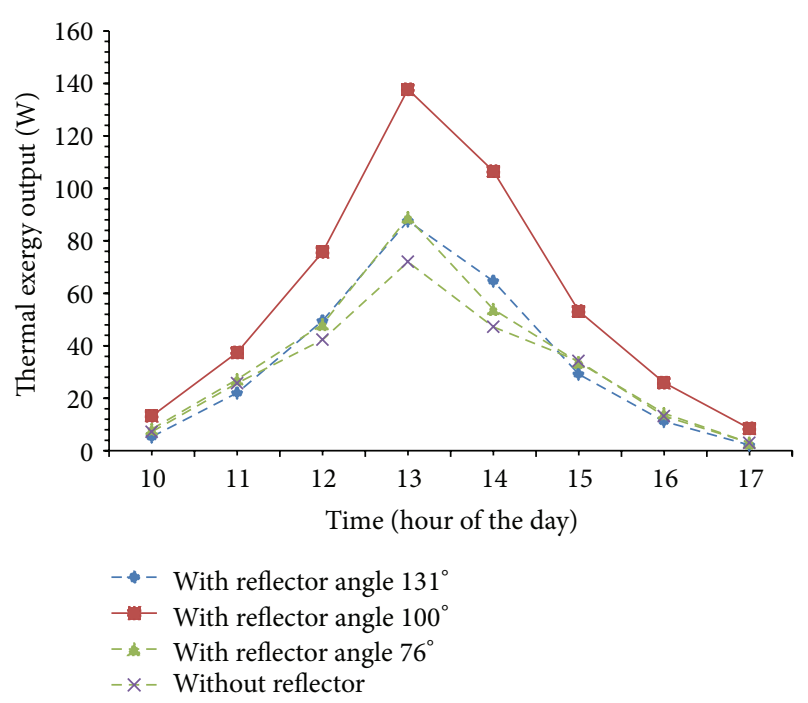

FIGURE 10: Variation of the thermal exergy output over the day for representative reflector inclinations compared with the system without the reflector.

the system, the work potential of the system increases. Exergy efficiency of the system can be used as a convenient parameter to determine the appropriate tilt of the reflector for a given system. The variation in maximum instantaneous total exergy efficiency (for a day) for different reflector tilts is illustrated in Figure 12. As observed, for the present system, the reflector angle in the range of $85-100^{\circ}$ has been found to be suitable in terms of enhanced system output and exergetic efficiency.

\section{Conclusions}

The present study has investigated the performance of a plane reflector integrated photovoltaic-thermal water heating

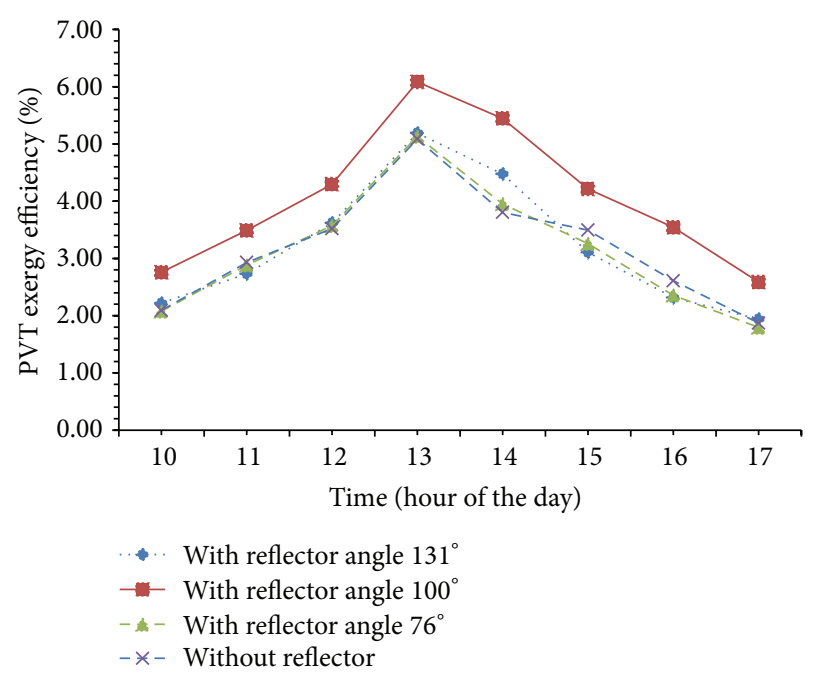

FIGURE 11: Variation of the system exergy efficiency over the day for representative reflector inclinations compared with the system without the reflector.

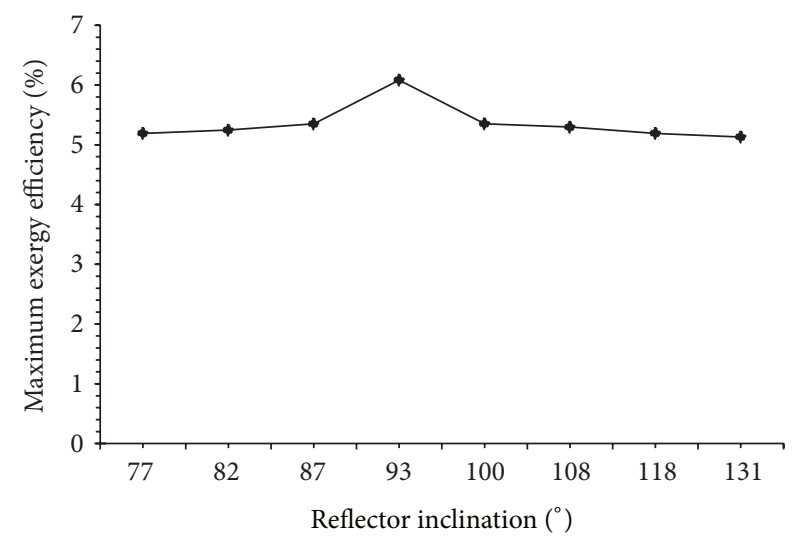

FIGURE 12: Variation of maximum system exergy efficiency for different reflector inclinations.

system for the tropical climate of Calicut quantified in terms of first law and second law efficiency of the system. It has been observed that there is a significant increase in the thermal and electrical output of the system with the addition of plane reflector to the system compared to the original system without the reflector. The performance of the system has been studied under various tilt angles of the reflector and has been compared with the base case without the reflector. At a reflector tilt of $100^{\circ}$, compared to the maximum module output without the reflector, 54\% increase in the maximum power output has been observed for a typical winter day for the location under study. Also, the maximum rate of thermal energy from the collector has been enhanced by $21 \%$ as compared to the case without the reflector. With enhancement of the system output with irradiance, the mean collector temperature and module temperature get elevated as compared to the base case which affects the energy efficiency of the system unfavourably. On an average the drop in efficiency for a typical winter day for the reflector integrated 
system is $15 \%$ as compared to the system without the reflector. The appropriate reflector tilt may be chosen in terms of the exergetic efficiency of the system. Both module exergy efficiency and collector exergy efficiency have been found to increase with the irradiance level on the collector. For the present system, the reflector angle in the range of $85-100^{\circ}$ has been found to be suitable in terms of enhanced system output and exergetic efficiency for the winter conditions of Calicut.

It would be of interest to study the effect of an additional reflector integrated to the lower edge of the collector and to study the system performance over the modified system for a complete year.

\section{Nomenclature}

A: Area, $\mathrm{m}^{2}$

$c_{p}$ : Specific heat, $\mathrm{J} / \mathrm{kg} \mathrm{K}$

$E$ : Enhancement factor

I: Current, ampere

$I_{T}$ : Incident solar irradiance on the collector plane, $\mathrm{W} / \mathrm{m}^{2}$

$\dot{m}$ : Mass flow rate, $\mathrm{kg} / \mathrm{s}$

P: Power, $\mathrm{W}$

$\dot{Q}_{u}$ : Useful heat gain, W

T: Temperature, $\mathrm{K}$

$V$ : Voltage, volt

$\dot{X}$ : Exergy transfer rate, W.

\section{Subscripts}

$\begin{array}{ll}0: & \text { Ambient } \\ c: & \text { Collector } \\ e: & \text { Electrical } \\ f_{i}: & \text { Fluid at inlet } \\ f_{o}: & \text { Fluid at outlet } \\ \text { in: } & \text { Input } \\ \text { PV: } & \text { Module }\end{array}$

PVT: Photovoltaic-thermal

s: $\quad$ Solar

$t$ : Thermal.

\section{Greek Letters}

$\beta$ : Collector tilt

$\varepsilon$ : Exergy efficiency

$\xi$ : Packing factor

$\psi$ : Reflector tilt

$\eta$ : Efficiency.

\section{Abbreviations}

PV: Photovoltaic

PV/T: Photovoltaic- thermal.

\section{Conflict of Interests}

The authors declare that there is no conflict of interests regarding the publication of this paper.

\section{References}

[1] T. T. Chow, "A review on photovoltaic/thermal hybrid solar technology," Applied Energy, vol. 87, no. 2, pp. 365-379, 2010.

[2] M. R. Islam, K. Sumathy, and S. U. Khan, "Solar water heater systems and their market trends," Renewable and Sustainable Energy Reviews, vol. 17, pp. 1-25, 2013.

[3] R. Tang, Y. Cheng, M. Wu, Z. Li, and Y. Yu, "Experimental and modeling studies on thermosiphon domestic solar water heaters with flat-plate collectors at clear nights," Energy Conversion and Management, vol. 51, no. 12, pp. 2548-2556, 2010.

[4] L. M. Ayompe and A. Duffy, "Analysis of the thermal performance of a solar water heating system with flat plate collectors in a temperate climate," Applied Thermal Engineering, vol. 58, pp. 447-454, 2013.

[5] H. A. Zondag, D. W. de Vries, W. G. J. van Helden, R. J. C. van Zolingen, and A. A. van Steenhoven, "The thermal and electrical yield of a PV-thermal collector," Solar Energy, vol. 72, no. 2, pp. 113-128, 2002.

[6] S. A. Kalogirou and Y. Tripanagnostopoulos, "Hybrid PV/T solar systems for domestic hot water and electricity production," Energy Conversion and Management, vol. 47, no. 18-19, pp. 33683382, 2006.

[7] S. Dubey and G. N. Tiwari, "Thermal modeling of a combined system of photovoltaic thermal (PV/T) solar water heater," Solar Energy, vol. 82, no. 7, pp. 602-612, 2008.

[8] T. T. Chow, G. Pei, K. F. Fong, Z. Lin, A. L. S. Chan, and J. Ji, "Energy and exergy analysis of photovoltaic-thermal collector with and without glass cover," Applied Energy, vol. 86, no. 3, pp. 310-316, 2009.

[9] A. Tiwari, S. Dubey, G. S. Sandhu, M. S. Sodha, and S. I. Anwar, "Exergy analysis of integrated photovoltaic thermal solar water heater under constant flow rate and constant collection temperature modes," Applied Energy, vol. 86, no. 12, pp. 2592-2597, 2009.

[10] P. Dupeyrat, C. Ménézo, M. Rommel, and H. Henning, "Efficient single glazed flat plate photovoltaic-thermal hybrid collector for domestic hot water system," Solar Energy, vol. 85, no. 7, pp. 1457-1468, 2011.

[11] S. Agrawal and G. N. Tiwari, "Energy and exergy analysis of hybrid micro-channel photovoltaic thermal module," Solar Energy, vol. 85, no. 2, pp. 356-370, 2011.

[12] F. Shan, L. Cao, and G. Fang, "Dynamic performances modeling of a photovoltaic-thermal collector with water heating in buildings," Energy and Buildings, vol. 66, pp. 485-494, 2013.

[13] W. He, Y. Zhang, and J. Ji, "Comparative experiment study on photovoltaic and thermal solar system under natural circulation of water," Applied Thermal Engineering, vol. 31, no. 16, pp. 33693376, 2011.

[14] C. S. Malvi, D. W. Dixon-Hardy, and R. Crook, "Energy balance model of combined photovoltaic solar-thermal system incorporating phase change material," Solar Energy, vol. 85, no. 7, pp. 1440-1446, 2011.

[15] J. W. Bollentin and R. D. Wilk, "Modeling the solar irradiation on flat plate collectors augmented with planar reflectors," Solar Energy, vol. 55, no. 5, pp. 343-354, 1995. 
[16] P. Nostell, A. Roos, and B. Karlsson, "Ageing of solar booster reflector materials," Solar Energy Materials and Solar Cells, vol. 54, no. 1-4, pp. 235-246, 1998.

[17] H. M. S. Hussein, G. E. Ahmad, and M. A. Mohamad, "Optimization of operational and design parameters of plane reflectortilted flat plate solar collector systems," Energy, vol. 25, no. 6, pp. 529-542, 2000.

[18] L. T. Kostić, T. M. Pavlović, and Z. T. Pavlović, "Optimal design of orientation of PV/T collector with reflectors," Applied Energy, vol. 87, no. 10, pp. 3023-3029, 2010.

[19] H. Tanaka, "Solar thermal collector augmented by flat plate booster reflector: optimum inclination of collector and reflector," Applied Energy, vol. 88, no. 4, pp. 1395-1404, 2011.

[20] H. F. Chiam, "Stationary reflector-augmented flat-plate collectors," Solar Energy, vol. 29, no. 1, pp. 65-69, 1982.

[21] M. Shihabudheen and P. Arun, "Performance evaluation of a hybrid photovoltaic-thermal water heating system," International Journal of Green Energy, vol. 11, no. 9, pp. 969-986, 2014.

[22] S. M. Jeter, "Maximum conversion efficiency for the utilization of direct solar radiation," Solar Energy, vol. 26, no. 3, pp. 231236, 1981. 


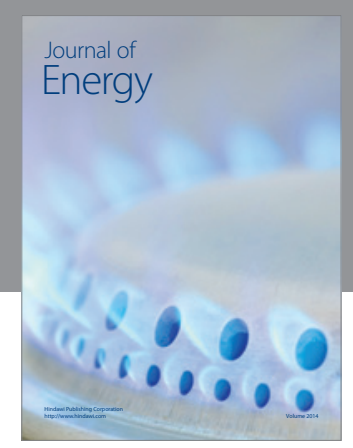

Journal of

Industrial Engineering
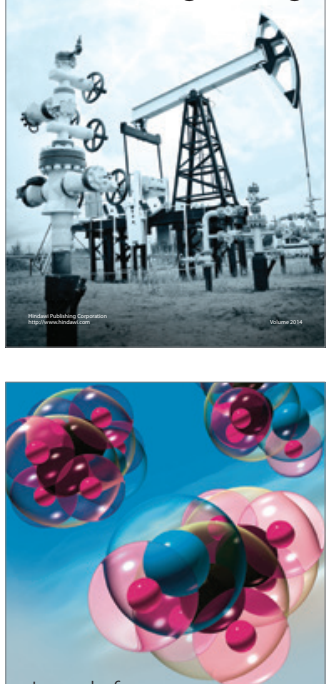

Fuels
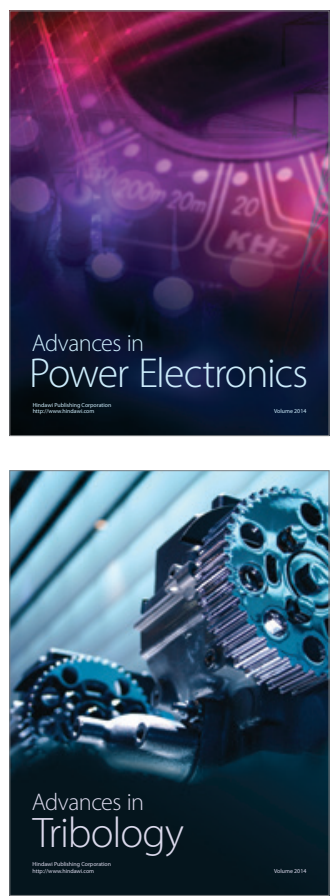

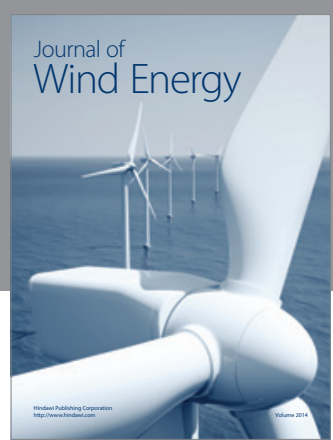

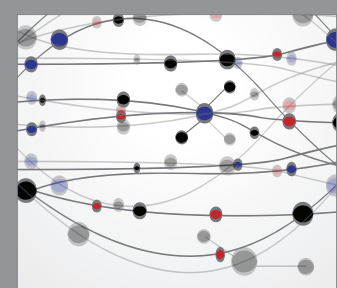

The Scientific World Journal

Submit your manuscripts at http://www.hindawi.com

Journal of

Structures
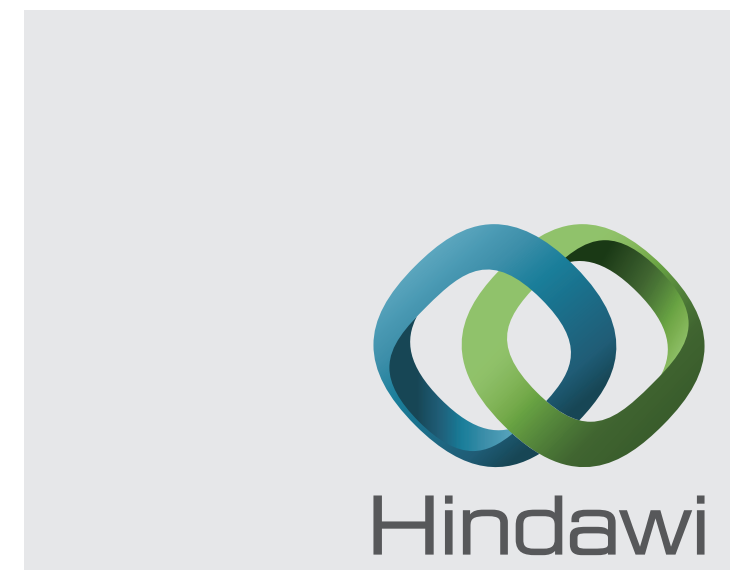

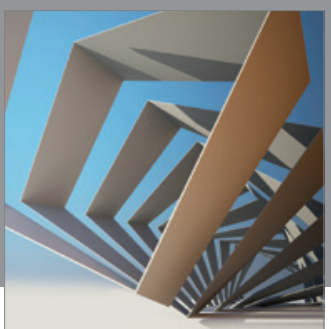

Rotating

Machinery
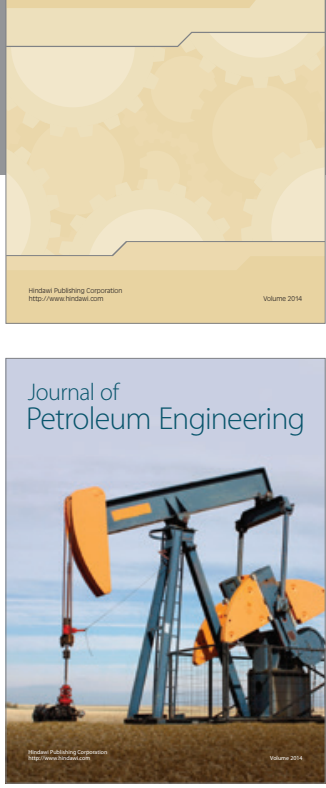

Journal of

Solar Energy
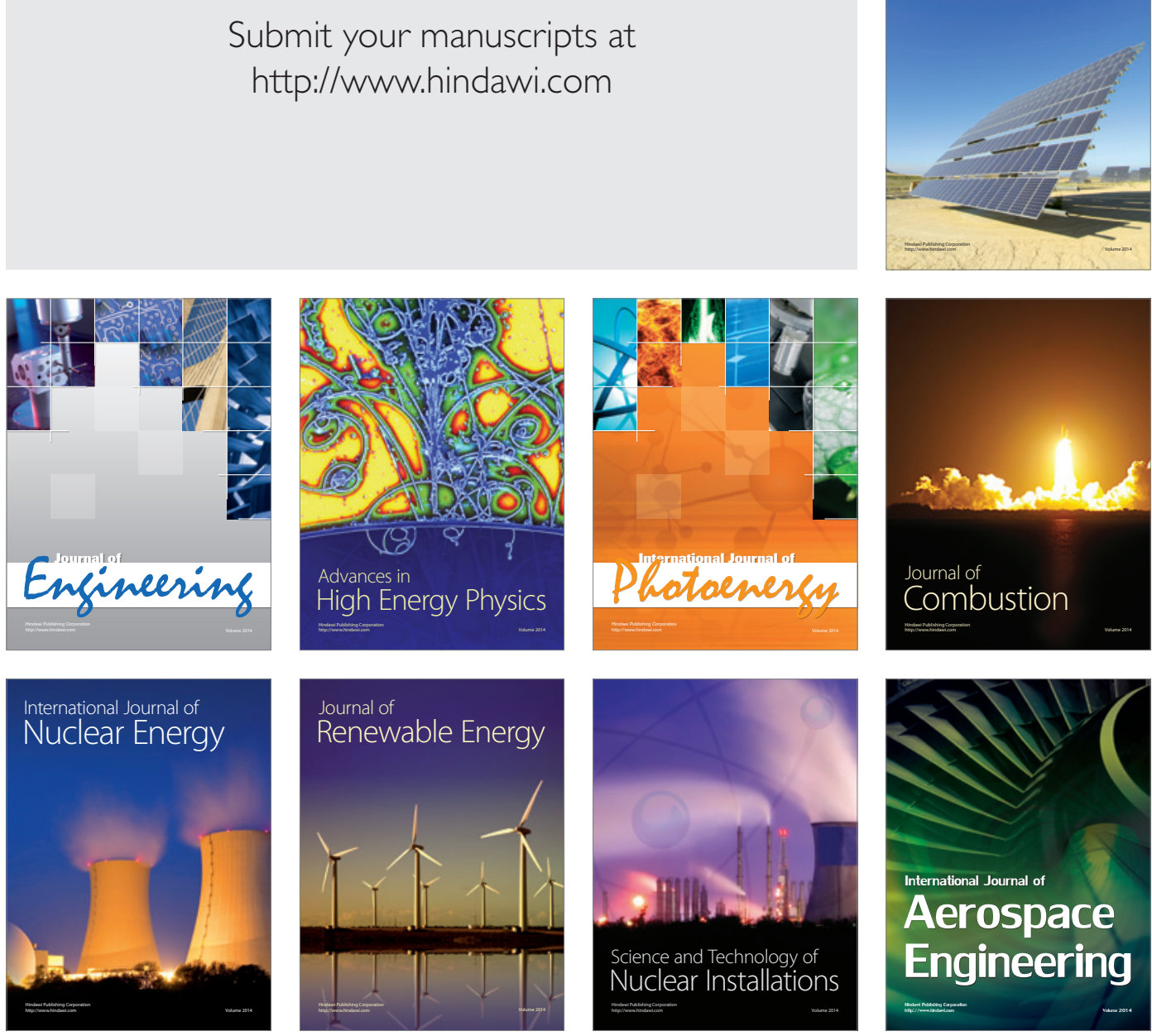